\title{
両眼網膜視差を持たないステレオグラムの輝度変化に対する奥行反応 ${ }^{1}$
}

\author{
九州大学下野䒬 - 2 \\ ヨーク大学 大 野僩
}

Perceived depth produced by luminance differences in the two eyes with zero disparity

Koichi Shimono (Department of Psychology, Faculty of Literature, Kyushu University, Higashi-ku, Fukuoka 812) and Hiroshi Ono (Department of Psychology, Faculty of Arts, York University, North York, Ontario, Canada, M3J 1P3)

We examined Kaufman, Bacon, and Barroso's (1973) finding that perceived depth covaries with relative luminance of the two half-fields of the stereogram. Five subjects were shown two sets of stereograms: one with three lines and another with random dots. In each trial, they reported the apparent depth plane produced by one of 15 different relative luminances of the lines or the mid portions of the random dots. The direction and the magnitude of perceived depth as a function of the relative luminance varied across subjects. It is argued that the stimulus should be considered as being Wheatstone-Panum's Limiting Case rather than that requires processing of binocular retinal disparity.

Key words: relative luminance, stereopsis, depth perception, Wheatstone-Panum's Limiting Case, zero disparity.

1838 年, Wheatstone は水平方向のずれ (両眼網膜視 差, binocular retinal disparity 以下, 網膜視差) を持っ た図形を両眼分離提示 (dichoptic presentation) すると 奥行印象が生じることを報告した. 網膜視差によって引 き起こされる，この奥行の知覚は両眼立体視 (binocular stereopsis) と呼ばれている. 一方, 絧膜視差を持たな い刺激を両眼分離提示しても奥行印象は生じると報告し た一群の研究がある。例えば Wheatstone-Panum の限 界条件 (一方の眼に 1 つ網膜像を，他方の眼に $2 つ 0$ 網膜像を作る刺激配置一以下 W-PLC)（例えば Panum, 1940/1858) や，両眼に提示された輪郭線間の明る さの差（例えば Foley, 1976; Kaufman, Bacon, \& Barroso，1973）が奥行をもたらす刺激条件として報告され ている.これらの網膜視差がない刺激でも奥行印象が生 じをという報告は，一般に認められた両眼立体視の概念 と明らかに矛盾する。

1 本研究は大野僩に対する the Natural Sciences and Engineering Research Council of Canada からの 研究費 (AO 296) によって援助されたものである。

2 現所属 東京商船大学社会科学教室. 本論文老交之 めるに要たり貴重な示唆をいただた福网教育大学中溝 幸夫助教授, 北九州大学近藤倫明助教授, Canada York 大学の Wa Tam James 博士に感謝いたします.
画眼立体視の枠組みから見た場合，これらの報告には 検討すべき問題がある。網膜視差を持たない刺激条件に 㧍いて奥行印象が確かに得られるかといら経験的問題 と，(もし確かに観察されるとするならば）その条件下で 得られた奥行印象を“雨眼立体視”のカテゴリーに入 れるべきかという理論的問題である.

理諭的問題の前提として, まず経験的問題について考 えてみよう。最近，いくつかの研究は，今まで “両眼 立体視”として考えられていた観察が明白なものでは ないことを示した．例えば，W-PLC がもたらす㒷行印 象は方向や量が一定ではなかった (Ono \& Wade, 1985； Shimono \& Ono, 1986). また, Foley (1976) の報告 した網膜視差のない刺激間の明るさの差が奥行をもたら すという現象も，その後の研究では確認されていない (Krol \& van de Grind, 1986; Tam \& Ono, 1987).

網膜視差のない刺激間の明るさの差が㒷行をもたらす という現象はまた Kaufman et al.(1973)によっても報 告されている. 彼らはステレオグラムの左右の単眼図形 (half-field) を重叔たものを両眼で観察させ，さらに一 方の眼に掠いてのみ最初のステレオグラムの 2 つの単眼 図形間の明るさの差を変化させたとき，見えの奥行量は その明るさの差に依存して変化すると報告した，本研究 の目的は，網膜視差がなくても奥行知覚が生じるという 
報告の 1 つ, Kaufman et al. (1973) による報告を確かめ ることであった. さらに, Kaufman et al. (1973) の報告 した現象を“両眼立体視”のカテゴリーに入れるべき かといら理論的問題についても討論した.

\section{方 法}

本実験では刺激として，Kaufman et al. (1973) と同 様, ランダムドットステレオグラム (random-dot stereogram 以下 RDS) と 2 組の 3 本の縦の線分からなる線 ステレオグラムを使った。

装置 RDS と線ステレオグラムはコンピュータ (LSI 11/23) で制御された Grinell Graphic System によって CRT (Hitachi HM-2713) 上に提示された. 被験者の角 膜表面から，眼の高さにある CRT の中央までの距離は $100 \mathrm{~cm}$ であった. 偏光フィルターが左右両眼の前と左 右の単眼図形の前に置かれた。 そのとき輻輳距離は約 $34 \mathrm{~cm}$, 輻輳角は約 $10.1^{\circ}$ であった. 被験者は調節と輻 輳との不一致を調整するために $-1.5 \mathrm{D}$ のレンズを通し て CRT を観察した.

刺激 (1) RDS の場合.まず 112 (横) $\times 256$ (縦)画素 からなる網膜視差を持つステレオグラム (primary stereogram, 以下 P-ステレオグラム) を作った．画素の大き さは $3.2^{\prime} \times 2.9^{\prime}$ ， ステレオグラム全体の大きさは $6.0^{\circ} \times$ $12.4^{\circ}$ であった. ステレオグラムの中の網膜視差を持つ 領域(中心領琙)は $56 \times 56$ 画素からなる矩形（大きさは $\left.3.0^{\circ} \times 2.7^{\circ}\right)$ であり，網膜視差の大きさは $6.5^{\prime}, 13.0^{\prime}, 19.4^{\prime}$ であった．次に P-ステレオグラムの左右の単眼図形(以 下 $\mathrm{P}$-単眼図形)を重衫て, 網膜視差を持たないステレオ グラム (new stereogram, 以下 N-ステレオグラム)の左 右の単眼図形（以下 $\mathrm{N}$-単眼図形）を作った。この $\mathrm{N}$ ステレオグラムが被験者に兩眼分離提示された. N-単 眼図形を作るときは 2 つの $\mathrm{P}$-単眼図形の輝度を画素ご とに加算した。左右の $\mathrm{N}$-単眼図形の平均輝度はいずれ む $5.8 \mathrm{~cd} / \mathrm{m}^{2}$ であった. 一方の $\mathrm{N}$-単眼図形を作るとき には, 左右の $\mathrm{P}$-単眼図形の輝度の相対寄与率は 1 対 1 $\left(2.9 \mathrm{~cd} / \mathrm{m}^{2}\right.$ 対 $\left.2.9 \mathrm{~cd} / \mathrm{m}^{2}\right)$ に保った $(\mathrm{Nc}$-単眼図形). 他 方の $\mathrm{N}$-単眼図形を作るときには, 一方の $\mathrm{P}$-単眼図形 の輝度を 0 から $5.8 \mathrm{~cd} / \mathrm{m}^{2}$ まで，他方の $\mathrm{P}$-単眼図形の 輝度を $5.8 \mathrm{~cd} / \mathrm{m}^{2}$ から 0 まで等間隔で変化させ, 輝度が 一定 $\left(5.8 \mathrm{~cd} / \mathrm{m}^{2}\right)$ になるように組み合わせた $(\mathrm{Nv}$-単眼 図形)。

（2）線ステレオグラムの場合. 刺激の作り方は RDS の場合と同じであった。 $6.5^{\prime} ， 13.0^{\prime} ， 19.4^{\prime}$ の網膜視差を 持つP-ステレオグラムの左右の単眼図形(縦の 2 本の線 分)のらち，左側の線分が重なるようにして $\mathrm{N}$-ステレ オグラムの単眼図形を作った (Kaufman et al, 1973 Fig. 1 夌参照). N-単眼図形の 3 本の線分の長さは

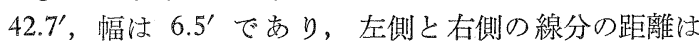

65'，中央と右側の線分との角距離は P-ステレオグラム の網膜視差の大きさに対応していたＮＮ-単眼図形の輝 度は一定であり，左側の線分では $5.8 \mathrm{~cd} / \mathrm{m}^{2}$, 中央と右 側の線分では $2.9 \mathrm{~cd} / \mathrm{m}^{2}$ であった. $\mathrm{NV}$-単眼図形の 3 本 の線分のうち，中央と右側にある線分の輝度が P-単眼 図形の輝度の相対寄与率によって変化した（左側の 1 本 の線分の輝度は一定であった)。

手続き RDS の場合も線ステレオグラムの場合も， 実験は 6 セッションから成り，それぞれのセッション内 では P-ステレオグラムの網膜視差の大きさと Nv-単眼 図形が提示される眼が一定であった. 網膜視差の大きさ の条件と Nv-単眼図形が提示される眼の条件の組み合 わせは被験者間で変えられた. 各セッションは4ブロッ クから成っており，それぞれのブロックでは 15 種類の $\mathrm{N}$-ステレオグラム ( $\mathrm{Nv}$-単眼図形において $\mathrm{P}$-単眼図形 の輝度の相対寄与率が異なる) がランダムな順序で提示 された。被験者は自由眼球運動下で刺激を観察した.

(1) RDS の場合. 調整刺激として赤い縦の線分 $\left(9.6^{\prime} \times 84.4^{\prime}\right)$ を $\mathrm{N}$-単眼図形の中央付近に提示した。 そ の線分は，初めに網膜視差がゼロであるか，あるいは Pーステレオグラムの 2 倍の, 交差性か非交差性の網膜視 差を持っていた. 被験者はその線分を，周辺領域から奥 行方向に“より離れている方の”中心領域と同じ平面 にくるように調整しだ・被験者はまず，調整刺激なしに CRT を観察し，中心領域が周辺領域の手前に見える か，後らに見えるか，あるいは同一面上に見えるかを口 頭で報告した. その後, 被験者はコントロールボックス のボタンを押してスクリーン上に調整刺激を提示し，ジ ヨイスティクを動かしてその刺激の網膜視差を，見えの 奥行に一致するように調整した。

(2) 線ステレオグラムの場合。調整刺激 $\left(6.5^{\prime} \times 58.0^{\prime}\right.$ の線分) は中央の線分と右端の線分の間, 上方に提示さ れた。ステレオグラムの線分の上端と調整刺激の下端は 垂直方向に 7.3' 離れていた. 被験者は調整刺激を, 知 覚された 3 本の線分のうち左端の線分を含む面を基準と して，奥行方向に“より離れている方の”線分と同じ 面上にくるように調整した ${ }^{3}$. また，被験者はどの線分 に合わせて調整したかを口頭で報告した，その場合， “中央の線分”, “右の線分”, あるいは “両方の線分” （2本の線分が同一面に見えた場合）の 3 つのカテゴリー が使われた。

被験者 21 歳から 36 歳までの4名の男性と 1 名の女 性が実験に参加した。彼らはステレオプシスに異常はな く，視力は正常であった.

3 被験者がしぱしぱ中心領域が 2 つの面 (1つは周辺 領域の手前か後万，もう1つは周辺領域と同じ面）に見 えると報告したのでこのような教示を行った. 


\section{結果と考察}

結果の分析の目的は知覚された奥行と P-単眼図形の 輝度の相対寄与率との関係を調べることであった．被験 者の調整した奥行量が，一方の $\mathrm{P}$-単眼図形の輝度の相 対寄与率の関数としてプロットされた（その単眼図形の 輝度が 0 であるとき，投影幾何学は見えの奥行が基準面 より “後ろ”であることを，1.0のときは “手前”で あることを予測する). 同一の相対寄与率であっても，知 覚された奥行量, 奥行の方向がブロックごとに必ずしも
一定ではなかったので，そのことを示すために一試行毎 の奥行量がプロットされた.

まず，RDS に対する反応が分析された．被験者の反 応には 2 っのタプがあった. 輝度の相対寄与率の変 化に関して見元の奥行量が徐々に変る連続的変化タイ プと階段状に変る不連続変化タイプである．Fig. 1(a) と Fig. 1(b) はそれぞれ連続的変化タイプと不連続的変 化タイプの典型的な例を示している (両者とも $\mathrm{Nv}$-単眼 図形が右眼に提示された場合の結果である)。各被験者 がぞのタイプを示したかを，Pーステレオグラムのそれぞ
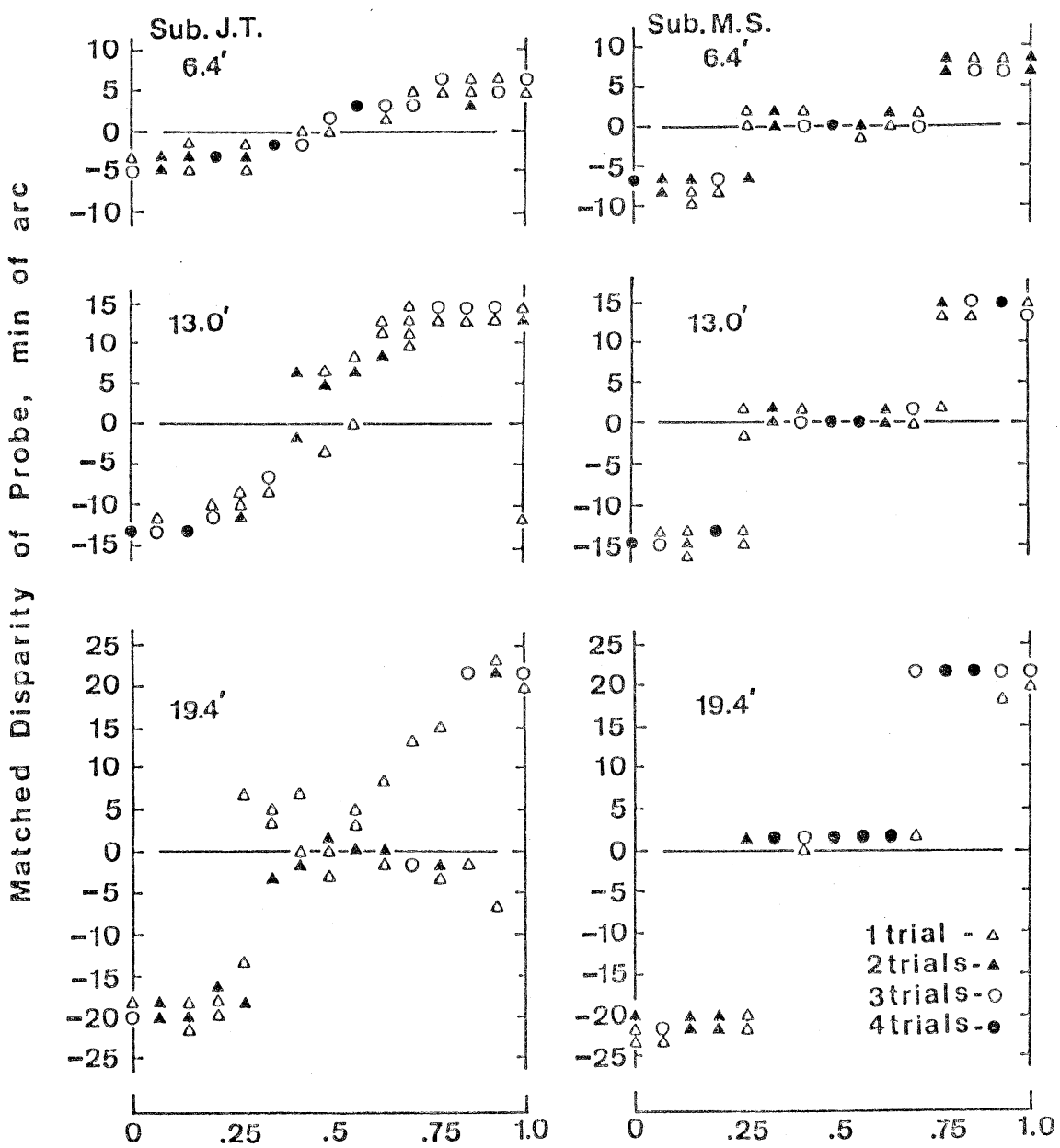

\section{Relative Luminance Ratio}

Fig. 1.RDS に対する反応の2つのタイプ。知覚された奥行が連続的に変化するタイプ (a) と不連続に変化する 夕イプ (b). 図中の記号 $\triangle$ は 1 つの試行の調整刺激の網膜視差量を示しており， 行，4試行で調整刺激の網膜視差量が等しかったことを示している。 
れの網膜視差の大きさごとに，Nv--単眼図形が提示され る眼, 輝度の相対㟢与率の範囲 (0 から 0.5 までと 0.5 から 1.0) の各条件で調べた. その結果, 被験者 M.S. 以外の全ての被験者において, Nv-単眼図形がいずれの 眼に提示されようとも反応のタイプは同じであった。網 膜視差が $6.5^{\prime}$ のときは, 輝度の相対寄与率の範囲が 0 から 0.5 の場合には 3 名が， 0.5 から 1.0 の場合には 5 名が, 13.0' と 19.4' のときには 1 名が連続的変化を示し た。被験者 M.S.の反応は網膜視差が 6.5'であり, Nv単眼図形が左眼に提示され, 輝度の相対寄与率の範国が 0.5 から 1.0 であったときにのみ, 連続的変化タイプ, その他の場合は不連続的変化タイプであった.

われわれの RDS に関するデータは, 見えの奥行は $\mathrm{P}$-単眼図形の輝度の相対寄与率によって連続的, あるい は不連続的に変化することを示した。連続的変化は Pステレオグラムの網膜視差が小さい場合, 不連続的変化 は, 網膜視差が大きい場合によく観察された.このこと は Kaufman et al. (1973) に報告された結果と矛盾は しない (Kaufman et a1., 1973. Fig. 5 及び Fig. 6 を参 照).ただし，これらの結果から Kaufman et al. (1973) のように，“見えの奥行の関数の形がステレオグラムの 網膜視差に依存して変化する”（p．46）とは言いきれな
い.というのはわれわれの結果では，見えの奥行の変化 の関数のタイプが, 網膜視差の大きさによって変化しな い被験者が見られたからである。たとえば, 被験者 K.S. と M.S. の反応は網膜視差の大きさに関わらず不 連続タイプであり, 被験者 J.T.のそれは連続的変化夕 イプであった.

次に線ステレオグラムに対する反応が分析された. 分 析の方法はRDS に対するものと同様であった. 線ステ レオグラムに対する反応には Fig. 1 に示したようなタ イプと同様に, 連続的変化タイプと不連続変化タイプが 見られた. 分析の結果, 各被験者の反応には, 被験者 M.S.の $6.5^{\prime}$ に詨する反応(連続的反応) と K.S.の $13.0^{\prime}$ と 19.4' に対する反応(不連続的反応) を除いて, 各網膜視差で両方のタイプの反応が見られた。しかしな がら，これらの両タイプの反応には，それぞれ見えの奥 行の方向が RDS に対する反応と異なる 2 つの反応があ った. 見えの奥行の方向が，投影幾何学の予測と反対で ある反応と，見えの奥行が一定でない反応であるＦｉg， 2(a)において，奥行を持つ線分は，常に左側の基準線 より後ろに定位されている. 反応は連続的変化をしてい るが，輝度の相対寄与率が 1.0 のとき奥行の方向は投影 幾何学の予測と反対の方向である. Fig. 2(b) において,
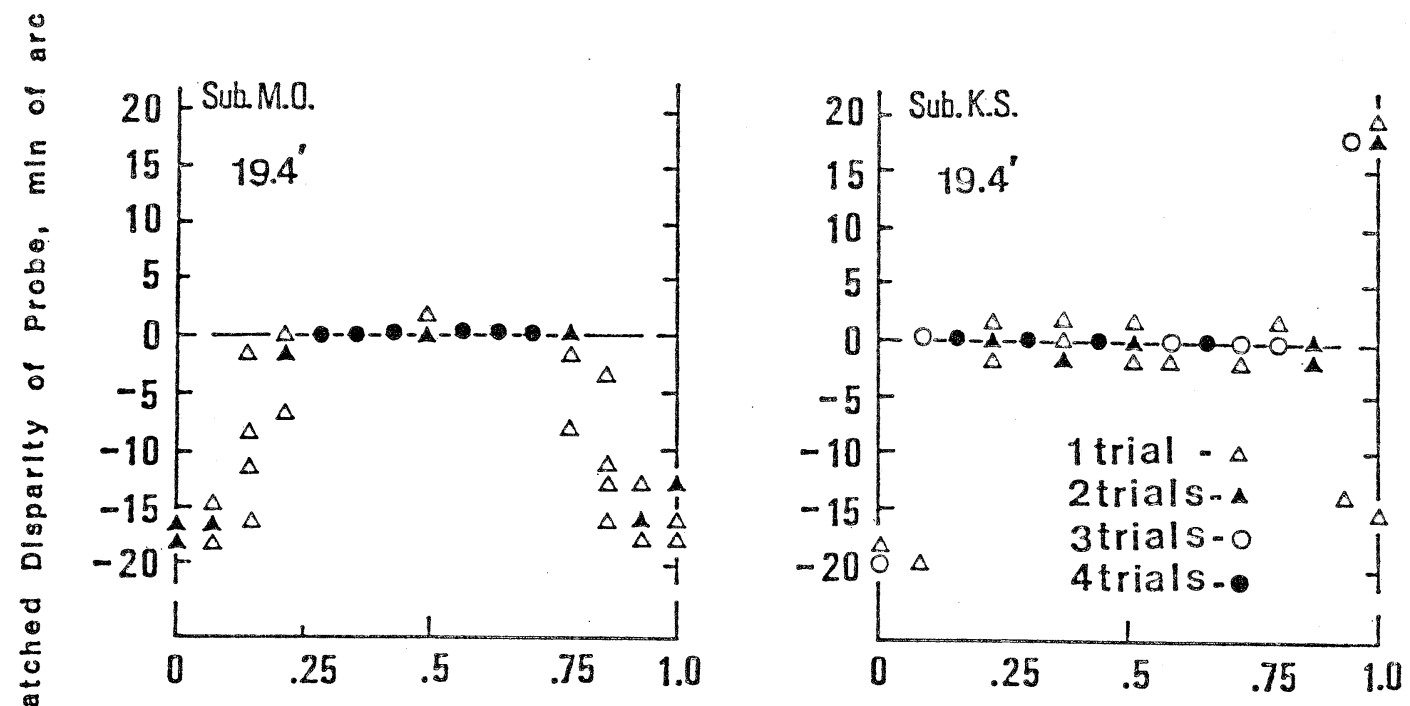

\section{Relative Luminance Ratio}

Fig. 2. 線ステレオグラムに特有な 2 つ反応. 奥行をるって知覚される線分の奥行の方向が, 投影幾何学の子測 と反対方向である反応 (a) (この図の場合, 輝度の相対奇与率が 1.0 のとき, 見えの奥行は手前と予測される) と, 輝 度の相対寄与率が同じとき, より離れて知覚される線分の奥行の方向が試行間で反対である反応 (b) (この図の場合 は 1.0 付近のとき). 図中の記号の意味は Fig. 1 と同様である. 
奥行量は不連続的変化をしているが, 1.0 付近のとき, 線分は類似の奥行量で手前に見えたり，後ろに見えたり している. Fig. 2(a) と（b) に示すような反応は，それ ぞれ網膜視差が $6.5^{\prime}$ のとき 1 名と 3 名, $13.0^{\prime}$ のとき 2 名と 1 名, 19.4' のとき 3 名と 2 名が示した. さらに線 ステレオグラムの結果の特徵は, 輝度の相対寄与率が 0 か 1.0 付近では, 基準線に対してより大きな奥行を持つ 線分が必ずしも常に同一の線分ではなかったことであ る.つまり, 相対寄与率が同じであっても, 試行によっ ては中央の線分のほうがより奥行を持って見えたり, 右 側の線分の方がより奥行を持って見えたりしたのであ る.

本実験の結果は，輝度の相対寄与率の変化が見えの奥 行に影響を及ぼしているという点では Kaufman et al. (1973)のそれと一致する. しかし, 相対寄与率の変化に 伴ら見えの奥行量, あるいは奥行方向の変化の仕方は彼 らの報告と一致するものばかりではなかった。この不一 致は, Kaufman et al. (1973) では被験者が2名であっ たために，彼らの結果が P-単眼図形間の輝度の相対寄 与率を変化させた時の奥行反応タイプの一部しか反映し ていないからであろう。

本実験結果が示すように, 輝度の相対寄与率の変化に 対する奥行反応の関数には幾つかのタイプが見いだされ た. 両眼立体視の理論にとって, 同一の網膜視差に対し ては見えの奥行が同一の方向, 類似の量を持っているこ とは自明のことであるから，このような反応の多様性は 両眼立体視の理論では説明することは困難である.むし ろ, この反応の多様性は W-PLC に関する実験結果 (例 えば, Gettys \& Harker, 1967; Ono \& Wade, 1985; Shimono \& Ono, 1986) と一致している.

本実験においては一方の $\mathrm{P}$-単眼図形の輝度の寄与率 がゼロであるとき, 提示された刺激は W-PLC として の刺激配置を含んでいる4. またゼロでない場合, 視覚系 がより輝度の低い画素, あるいは線分を検出できないと 仮定すると，W-PLC の条件は満たされる. 一般に WPLC は両眼立体視の融合理論, つまり投影幾何学によ る予測と一致する奥行を生むと考えられていた(例えば, Ogle, 1962). もし，その考えを受け入れるならば，本実 験結果も, Kaufman et al. (1973) の結果も投影幾何学の 予測と矛盾しているので，それぞれの実験に使われた刺 激配置を W-PLC と解釈することは困難である (Kauf-

4 RDS の場合，一方の眼で P-単眼図形を，他方の眼 で N-単眼図形を観察したとき，中心領域の画素のうち 確率的には $50 \%$ が W-PLC としての刺激配置となりう る. man et al, 1973 を参照). しかし, 最近の研究結果に よると W-PLC のもたらす奥行の方向も量も一定では ないことが明らかにされている (Gettys \& Harker, 1967 ; Ono \& Wade, 1985 ; Shimono \& Ono, 1986). 本 実験結果もまた見えの奥行の量も方向も一定にはならな いことを示した.これらのことは本実験で得られた奥行 が，W-PLC によるといら解釈と矛盾しない.

Ono \& Wade (1985) は W-PLC が常に一定の奥行を もたらすわけではないのは, 視覚系が網膜視差以外の奥 行手がかり, たとえば, 眼球運動手がかりや遮蔽手がか りを利用するためであると指摘している. 同様の議論が 本実験結果にも適用できる. Kaufman et al. (1973) が 観察した奥行は提示された刺激の持つ “網膜視差”が 処理されたものではなく, その刺激が含むW-PLC に よってもたらされたものであろう.

\section{引用文献}

Foley, J.M. 1976 Binocular depth mixture. Vision Research, 16, 1263-1267.

Gettys, C., \& Harker, G. 1967 Some observations and measurements of the Panum's phenomenon. Perception EF Psychophysics, 2, 387-395.

Kaufman, L., Bacon, J., \& Barroso, F. 1973 Stereopsis without image segregation. Vision Research, 13, 137-147.

Krol, J. D., \& van de Grind, W. A. 1986 Binocular depth mixture : an artefact of eye vergence? Vision Research, 26, 1289-1298.

Ogle, K. N. 1962 The optical space sense. In H. Davson (Ed.), The eye. Vol. 4. New York: Academic Press. Pp. 211-417.

Ono, H., \& Wade, N. 1985 Resolving discrepant results of the Wheatstone Experiment. Psychological Research, 47, 135-142.

Panum, P. L. 1940 Physiological investigations concerning vision with two eyes. (Trs. by C. Heubsher) Hanover, N. H. : Dartmouth Eye Institute. (Physiologische Untersuchungen über das Sehen mit zwei Augen. 1858 Kiel: Schwers.

Shimono, K., \& Ono, H. 1986 Occlusion as a cue for the depth in Wheatstone-Panum's Limiting Case. Investigative Ophthalmology \& Visual Science, Supplement, 27, 346.

Tam, W. J., \& Ono, H. 1987 Zero horizontal disparity in binocular depth mixture stimuli. Vision Research, 27, 1207-1210.

-1987. 10.30. 受稿, 1990. 3. 17. 受理一 